\title{
KEEFEKTIFAN PENGGUNAAN MEDIA VIDEO DALAM KETERAMPILAN MENULIS KARANGAN SEDERHANA BAHASA JERMAN SISWA KELAS XII IPA SMA NEGERI 11 MAKASSAR
}

\author{
Hardianti $^{1}$ dan Wahyu Kurniati Asri ${ }^{2}$ \\ Fakultas Bahasa dan Sastra, Universitas Negeri Makassar \\ E-mail ${ }^{1}:$ 18dhyanhardianti@gmail.com
}

\begin{abstract}
ABSTRAK
Tujuan dari penelitian ini ialah untuk mengetahui efektivitas media video dalam meningkatkan keterampilan menulis karangan sederhana bahasa Jerman siswa kelas XI IPA SMA Negeri 11 Makassar. Jenis penelitian yang digunakan yakni quasi eksperimen. Populasi dalam penelitian ini adalah seluruh kelas XI SMA Negeri 11 Makassar yang terdiri atas 10 kelas, dengan jumlah siswa 300 orang. Sampel yang digunakan dalam penelitian ini adalah siswa kelas XI IPA 5 berjumlah 30 orang sebagai kelas eksperimen dan kelas XI IPA 7 yang berjumlah 30 orang sebagai siswa kelas kontrol yang dipilih secara acak. Hasil penelitian menunjukkan bahwa penggunaan Media Video efektif dalam keterampilan menulis karanagn sederhana bahasa Jerman kelas XI IPA SMA Negeri 11 Makassar. Hasil uji- $t$ menunjukkan bahwa nilai $t_{\text {hitung }}=3,79>t_{\text {tabel }}=2,002$ dengan taraf signifikan 0,05 .
\end{abstract}

Kata Kunci : Media Video, Keterampilan Menulis, Karangan Sederhana, dan Bahasa Jerman

\begin{abstract}
The purpose of this study is to obtain data and information about the skill of writing simple essay German class XI IPA SMA Negeri 11 Makassar. This research is Quasi experiment research. Data were analyzed by inferential statistics with t-test. The population of this research is students of class XI IPA SMA Negeri 11 Makassar consisting of 10 classes. The sample used is a random sample (Random Sampling). The number of samples are 2 classes like class XI IPA 5 as the experimental class consisting of 30 students and class XI IPA 7 as the control class consisting of 30 students. The result of data analysis showed that $\mathrm{Th} 3.79>\mathrm{Tt}$ 2,002 at significant level 0,05 . The results show that the use of video media is effective in the skill of writing simple essay German language class XI SMA Negeri 11 Makassar.
\end{abstract}

Keywords: Video Media, Writing Skill, Simple Essay, and German Language

\section{PENDAHULUAN}

Manusia merupakan makhluk sosial yang tak terlepas dari interaksi dengan sesama pemakai bahasa dalam kehidupan sosial. Bahasa tersebut digunakan sebagai media penyampaian ide, gagasan, dan pesan baik secara lisan maupun tulisan. Penyampaian informasi tersebut melibatkan berbagai jenis bahasa, yakni bahasa nasional, dan international. Hal ini yang mendasari manusia untuk senantiasa meningkatkan kemampuan dan keterampilan berbahasanya menuju pribadi 
yang berwawasan luas dan berbudaya. Oleh sebab itu, bahasa dijadikan sebagai salah satu materi ajar dalam proses belajar mengajar pada setiap jenjang pendidikan.

Pembelajaran bahasa Jerman di Sekolah Menengah Atas (SMA) dan sederajat menerapkan kurikulum 2013 sebagai acuan dalam menyusun perencanaan dan materi ajar. Pembelajaran tersebut terdiri atas empat kompetensi yakni kemampuan mendengar (Hörverstehen) serta kemampuan membaca memahami (Leseverstehen) yang merupakan bagian dari kompetensi berbahasa yang bersifat reseptif. Keterampilan menulis (Schreibfertigkeit) serta keterampilan berbicara (Sprechfertigkeit) yang merupakan kompetensi berbahasa yang bersifat produktif. Selain keempat kompetensi tersebut, pembelajaran bahasa Jerman juga ditunjang oleh kedua kompetensi pendukung yakni tata bahasa dan kosakata (Strukturen und Wortschatz).

Media merupakan salah satu faktor penentu keberhasilan pembelajaran (Mantasiah, 2016). Melalui media video, pembelajaran lebih menarik dan menyenangkan. Aspek penting penggunaan media video adalah membantu memperjelas materi, maka media berperan sebagai alat bantu untuk memperjelas pesan yang disampaikan dalam proses belajar mengajar.

Penggunaan media video dapat merangsang pengetahuan siswa, melatih berpikir logis, analistik, lebih kreatif, efektif, mempertajam daya imajinasi siswa dan menyenangkan. Siswa juga diberikan kesempatan untuk berdiskusi mengenai teks karangan sederhana dalam bahasa Jerman, saling memahami satu sama lain, saling bertukar informasi, sehingga siswa akan memeroleh pemahaman mengenai pembelajaran menulis yang lebih luas.

Dasar pertimbangan memilih video sebagai media pembelajaran agar dapat melatih siswa berpikir logis, konkrit, lebih realistis, dan siswa lebih terfokus pada media pembelajaran yang baru seperti media video ini, kemudian proses belajar lebih aktif, kreatif, dan berkesan. Dengan pemanfaatan media video ini diharapkan mampu meningkatkan kemampuan siswa, utamanya dalam keterampilan menulis karangan sederhana.

Keterampilan menulis merupakan salah satu kompetensi inti pada kurikulum 2013 yang difokuskan pada keterampilan siswa dalam menyusun dan memproduksi teks tulis sederhana untuk mengungkapkan informasi sesuai topik yang dipelajari dengan memperhatikan unsur kebahasaan, struktur teks (kata, frasa dan kalimat) dan unsur budaya yang sesuai dengan konteks penggunaannya.

Berdasarkan observasi dalam Praktik Pengenalan Lapangan (PPL) yang telah dilakukan oleh peneliti pada tanggal 7 Sepetember 2015 di SMA Negeri 11 Makassar diperoleh informasi bahwa salah satu faktor yang menyebabkan siswa mengalami kesulitan dalam mengembangkan ide atau gagasan dalam tulisan adalah kurang bervariasinya media yang digunakan dalam pembelajaran.

Kesulitan siswa dalam mengungkapan ide atau gagasan didukung oleh beberapa penelitian yakni: Rosnaini (2012:40) menunjukkan bahwa keterampilan menulis karangan sederhana bahasa Jerman melalui media video siswa kelas XI SMA Negeri 5 Makassar masih kurang (47,33\%). Hanesa (2011:44) menunjukkan bahwa peran media video 
dalam keterampilan menulis karangan sederhana pada siswa kelas XI SMA Negeri 4 Tanjung Pinang (45,65\%). Hafiah (2016:63) menyatakan bahwa keterampilan menulis dongeng bahasa Jerman menggunakan media gambar siswa kelas XII IPA Madrasah Aliyah Negeri (MAN) 1 Makassar termasuk kategori kurang $(32,56 \%)$.

Media video merupakan salah satu faktor penentu keberhasilan pembelajaran. Melalui media video proses pembelajaran lebih menarik dan menyenangkan. Informasi yang disampaikan secara lisan terkadang tidak dipahami sepenuhnya oleh siswa, terlebih lagi guru kurang cakap dalam memperjelas materi, maka media berperan sebagai alat bantu untuk memperjelas pesan yang disampaikan dalam proses belajar mengajar.

Penelitian lain yang menggunakan media sebagai acuan dalam meningkatkan proses pembelajaran yakni: Sueca (2010:55) mengatakan bahwa penggunaan media video pantomim dalam keterampilan menulis naskah drama bahasa Jerman kelas $X$ SMAN 1 Polongbangkeng dalam kategori baik (80,72\%). Asriyani (2011:64) mengatakan bahwa kemampuan menulis puisi bebas dengan menggunakan media video bahasa Jerman kelas XI IPA SMAN 6 Ujung Loe Kabupaten Bulukumba dalam kategori sangat baik $(83,50 \%)$. Selanjutnya Setyowati (2011:53) mengatakan bahwa penggunaan media video dalam keterampilan menulis kalimat sederhana bahasa Jerman siswa kelas X SMAN 5 Banjarmasin dalam kategori baik $(82,57)$.

\section{MEDIA PEMBELAJARAN}

Dalam bahasa Arab media diartikan sebagai "modeo" yang artinya perantara antara pengantar pesan dari pengirim ke penerima pesan. Arsyad (2011:4) berpendapat bahwa: "Media pembelajaran meliputi alat yang secara fisik digunakan untuk menyampaikan isi materi pembelajaran, yang terdiri atas buku, tape recorde, kaset, video kamera, video recorder, film, slide gambar (gambar bingkai), foto, gambar, grafik, televisi, dan komputer". Pendapat dari Anitah (2008:2) mengatakan bahwa "Media pembelajaran adalah setiap orang, bahan, alat, atau peristiwa yang dapat menciptakan kondisi yang memungkinkan pembelajar menerima pengetahuan, keterampilan, dan sikap". Selain itu Sabir (2005:112) mengatakan bahwa "Media belajar merupakan benda yang dimanipulasi, dilihat, didengar, dibaca atau dibicarakan beserta instrumen yang dipergunakan dengan baik dalam kegiatan belajar mengajar, dapat mempengaruhi efektifitas program instruksional".

Dari beberapa pendapat di atas dapat disimpulkan bahwa media pembelajaran adalah sebuah alat, bahan, dan peristiwa yang dapat dilihat, didengar, dibaca atau dibicarakan yang digunakan untuk menyalurkan pesan dari pengirim ke penerima sehingga dapat merangsang permikiran, minat, perhatian siswa sehingga proses pembelajaran lebih terarah.

\section{MEDIA VIDEO}

Video merupakan salah satu media audio visual yang banyak dikembangkan untuk keperluan pembelajaran karena dapat meningkatkan hasil pembelajaran. Media audio visual dapat menampilkan unsur gambar (visual) dan suara (audio) secara bersamaan pada saat mengkomunikasikan pesan atau informasi. Media video 
diklasifikasikan sebagai media audiovisual.

Pendapat Arsyad dalam Wiarto (2016:136) yang menyatakan bahwa: "Video merupakan gambar-gambar dalam frame, di mana frame demi frame diproyeksikan melalui lensa proyektor secara mekanis sehingga pada layar terlihat gambar hidup". Kemudian pendapat dari Daryanto (2010:90) mengatakan bahwa "Video merupakan bahan ajar non cetak yang kaya informasi dan lugas karena dapat sampai di hadapan siswa secara langsung, video menambah suatu dimensi baru terhadap pembelajaran". Selanjutnya pendapat dari Ahmad (2007:4) bahwa: "Guru dan media pendidikan hendaknya bahu-membahu dalam memberikan kemudahan belajar bagi siswa. Perhatian dan bimbingan secara individual dapat dilaksanakan oleh guru dengan baik, sementara informasi dapat pula disajikan secara jelas, menarik dan teliti oleh media pendidikan".

Video dapat memberikan model yang lebih realistis kepada siswa sehingga siswa dapat berperan aktif dalam pembelajaran. Selain itu, dapat mempermudah pembelajaran bahasa karena disertai penguatan visual langsung bahasa Jerman, sehingga dari apa yang mereka dengar dan mereka lihat bisa menuangkannya ke dalam bentuk karangan sederhana bahasa Jerman.

Manfaat media video menurut Aqib (2013:51) antara lain: 1) Pembelajaran lebih jelas dan menarik;2) proses belajar lebih interaksi; 3) efisiensi waktu dan tenaga; 4) meningkatkan kualitas hasil belajar; 5) belajar dapat dilakukan dimana dan kapan saja; 6) menumbuhkan sikap positif belajar terhadap proses dan materi belajar; 7) meningkatkan peran guru ke arah yang lebih positif dan produktif".

Selanjutnya kelebihan media video menurut Rusman (2012:220) yaitu: 1) video dapat memberikan pesan yang dapat diterima lebih merata oleh siswa; 2) video sangat bagus untuk menerangkan suatu proses; 3) mengatasi keterbatasan ruang dan waktu, lebih realistis dan dapat diulang atau dihentikan sesuai kebutuhan, serta; 4) memberikan kesan yang mendalam, yang dapat mempengaruhi sikap siswa".

Selain itu pendapat dari Kustandi dan Sutjipto (2013:64-65) menambahkan kelemahan media video yaitu: 1) pengadaan media video memerlukan biaya yang sangat mahal dan waktu yang banyak; 2) pada saat pemutaran video gambar dan suara akan berjalan terus; 3 ) tidak semua siswa mampu mengikuti informasi yang disampaikan melalui media video".

Beberapa pendapat di atas dapat disimpulkan bahwa dalam media terdapat manfaat, serta memiliki kekurangan dan kelebihan. Dengan adanya proses pembelajaran yang menggunakan media video, siswa dapat mengefisienkan waktu dalam belajar, memberikan pengalaman yang baru kepada siswa, dan memberikan informasi yang akurat, dan lebih menarik, tetapi menyita banyak waktu dan memerlukan biaya yang cukup mahal.

\section{HAKIKAT MENULIS}

Pendapat dari Suparno dan Yunus (2010:1-3) "Menulis bukan hanya menyalin tetapi juga mengekspresikan pikiran dan perasaan ke dalam lambang-lambang tulisan". Selanjutnya menurut Alek (2010:106) mengatakan bahwa "Menulis merupakan salah satu dari empat keterampilan berbahasa. Menulis bukan 
hanya menyalin tetapi juga mengekspresikan pikiran dan perasaan ke dalam lambang-lambang tulisan". Selanjutnya pendapat dari Widodo (2008:92) mengemukakan bahwa "Writing is not only a tool for communication, but also it serves as a means of learning, thinking, and organizing knowledge of ideas". Maksud dari kutipan di atas adalah menulis bukan hanya sebuah alat untuk berkomunikasi namun juga dapat berfungsi sebagai alat untuk belajar, berfikir, dan mengatur pengetahuan atau ide. Selain itu pendapat Rosidi (2009:2-3) mengatakan "Menulis merupakan kegiatan seseorang untuk menyampaikan gagasan kepada pembaca dalam bahasa tulis agar dipahami oleh pembaca". Kemudian menurut Steets und Ehlich (2003:1) menulis adalah sebuah media komunikasi ilmiah, sebuah keterampilan dalam mengarang atau menyusun satu teks ilmiah".

Berdasarkan pendapat di atas dapat disimpulkan bahwa menulis merupakan suatu kegiatan yang digunakan seseorang untuk menyampaikan pokok pikiran, gagasan, dan perasaan dalam bentuk tulisan yang dapat di pahami seseorang dan juga dapat berfungsi sebagai alat komunikasi secara tidak langsung.

\section{KARANGAN SEDERHANA}

Menulis karangan sederhana dapat menuangkan ide, hasil pemikiran dari seseorang atau ungkapan perasaan ke dalam bentuk tulisan yang teratur dan dapat dimengerti maknanya. Indrawan (2009:06) mengemukakan bahwa menulis karangan sederhana adalah karya tulis atau hasil karya dari kegiatan seseorang untuk mengungkapkan gagasan dan menyampaikan melalui bahasa tulis secara sederhana yang disampaikan kepada pembaca untuk dipahami dalam suatu paragraph atau lebih dengan menggunakan beberapa kalimat-kalimat sederhana".

Selanjutnya pendapat dari Kokasih (2002:32) mengatakan bahwa "Menulis karangan sederhana adalah bentuk tulisan yang mengungkapkan pikiran dan perasaan pengarang dalam satu kesatuan tema yang utuh".

Adapun pendapat Anwar (2011:14) dari bahwa menulis karangan sederhana diperoleh dari suatu proses dimana ide yang ada dilibatkan dalam suatu kata, kata-kata yang terbentuk kemudian dirangkai menjadi sebuat kalimat. Kalimat disusun menjadi sebuat paragraf dan akhirnya paragrafparagraf tersebut mewujudkan sebuah karangan sederhana".

Dengan demikian, pendapat para ahli di atas dapat disimpulkan bahwa menulis karangan sederhana adalah sebuah hasil karya untuk mengungkapkan suatu gagasan, ide topik atau pokok bahasan yang disampaikan dalam suatu kesatuan karangan sederhana yang utuh, melalui sebuah tata tulisan yang mampu dimengerti maknanya.

Langkah-langkah menulis karangan yang juga dikemukakan oleh Jauhari (2013:122) yakni menentukan tema karangan sederhana, mengumpulkan ide atau bahan karangan sederhana, menyusun karangan, lalu mengembangkan karangan tersebut sehingga menjadi sebuah karangan yang sebenarnya.

Adapun pendapat dari Heuken (2008:10) sebagai berikut 1) ide harus jelas dan fokus; 2) memahami teknik mengarang; 3) mempelajari tata bahasa agar tulisan mudah dimengerti pembaca; 4) pengungkapan harus jelas, teratur, tanpa 
rasa emosional yang berlebihan dan harus realistis.

Berdasarkan pendapat di atas dapat disimpulkan bahwa untuk membuat sebuah karangan harus memperhatikan tema, topik kejelasan dan ketetapan isi, pilihan kata, struktur kalimat, tata bahasa, mudah, sederhana, langsung, tepat sehingga dapat tersusun dengan baik sesuai dengan peristiwa yang terkait dan saling berkaitan satu sama lain.

\section{METODE PENELITIAN}

Jenis penelitian yang digunakan penulis untuk meneliti atau mengetahui ada atau tidaknya pengaruh penggunaan media video terhadap peningkatan hasil belajar siswa pada pelajaran bahasa Jerman SMA Negeri 11 Makassar adalah penelitian Quasi Eksperimen (eksperimen semu). Penelitian ini menggunakan kelas eksperimen dan kelas kontrol. Penelitian ini melibatkan dua kelompok yaitu kelas eksperimen yang menggunakan media video dan kelas kontrol yang tidak menggunakan media video.

Media video merupakan salah satu media pembelajaran. Untuk memahami makna dari kedua variabel penelitian ini, maka akan dikemukakan pada defenisi operasional variabel. Pada variabel bebas (x) yaitu penggunaan media video, siswa melihat tayangan video tentang die Familie kemudian siswa menanggapi, menanyakan, dan mengidentifikasi informasi yang terdapat dalam video. Video ditayangkan 3 kali kemudian siswa membuat karangan sederhana tentang die Familie berdasarkan video yang telah ditayangkan. Selanjutnya veriabel terikat (y) menulis karangan sederhana bahasa Jerman dalam buku paket
Deutsch ist einfach 2 dengan tema "Die Familie".

Populasi dalam penelitian ini adalah seluruh kelas XI SMA Negeri 11 Makassar yang terdiri atas 10 kelas, dengan jumlah siswa 300 orang. Sampel yang digunakan dalam penelitian ini adalah siswa kelas XI IPA 5 berjumlah 30 orang sebagai kelas eksperimen dan kelas XI IPA 7 yang berjumlah 30 orang sebagai siswa kelas kontrol yang dipilih secara acak (Random Sampling). Dengan demikian jumlah sampel yang digunakan dalam penelitian ini sebanyak 60 orang.

Instrumen yang digunakan dalam penelitian ini adalah :

1. Tes awal (Pre-test) yaitu tes yang diberikan kepada siswa di awal penelitian yang bertujuan untuk mengetahui tingkat kemampuan awal siswa terhadap materi dengan tema die Familie yang akan diajarkan. Instrumen tersebut berupa soal membuat karangan sederhana.

2. Tes akhir (Post-test) merupakan tes kemampuan yang diberikan kepada siswa setelah diajar dengan tema die Familie. Tes ini bertujuan untuk mengetahui bagaimana tingkat pencapaian siswa baik yang berada di kelas experimen yang menerapkan media video maupun di kelas kontrol.

Teknik analisis data dalam penelitian ini menggunakan analisis statistika deskriptif dan inferensial untuk menguji hipotesis penelitian dengan menggunakan uji-t. Sebelum melakukan pengujian tersebut terlebih dahulu dilakukan uji normalitas dengan menggunakan tabel Z-score, chi kuadrat, dan uji homogenitas dengan menggunakan uji F (Fisher). Sebelum menentukan uji 
normalitas data dan homogenitas maupun uji hipotesis terlebih dahulu tentukan nilai rata-rata (mean), simpangan baku dan varian.

\section{HASIL DAN PEMBAHASAN}

Pada bagian ini disajikan hasil analisis data yang diperoleh dari hasil tes siswa tentang die Familie, baik di kelas eksperimen maupun di kelas kontrol. Kedua kelas tersebut terlebih dahulu diberikan pretest dengan soal yang sama untuk mengetahui keterampilan menulis Bahasa Jerman siswa. Setelah pemberian pre-test pada masing- masing kelas, selanjutnya, diberikan perlakuan yang berbeda. Kelas eksperimen diberikan perlakuan yaitu penggunaan media video dalam keterampilan menulis karangan sederhana bahasa Jerman. Sedangkan pada kelas kontrol tetap menggunakan pembelajaran yang konvensional. Setelah dilakukan empat kali pertemuan, kedua kelas tersebut diberikan post- tes, selanjutnya akan dilakukan analisis data.

Pada penelitian ini, proses pembelajaran dilakukan selama 4 kali pertemuan. Dalam pembelajaran tersebut kedua kelas tersebut diajarkan menggunakan media yang berbeda. Pada kelas eksperimen siswa diajarkan dengan menggunakan media video dalam keterampilan menulis karangan sederhana bahasa Jerman, sedangkan pada kelas kontrol diajarkan pembelajaran yang konvensional. Analisis data penelitian tentang keefektifan penggunaan media video dalam keterampilan menulis karangan sederhana bahasa Jerman siswa kelas XI IPA SMA Negeri 11 Makassar, seperti yang di paparkan di atas bahwa terdapat perolehan skor siswa yang menggunakan media video lebih tinggi dibandingkan dengan siswa yang menggunakan pembelajaran konvensional dalam keterampilan menulis karangan sederhana bahasa Jerman pada SMA Negeri 11 Makassar.

Dengan demikian, $\mathrm{H}_{1}$ yang menyatakan bahwa ada perbedaan yang signifikan antara keterampilan menulis karangan sederhana bahasa Jerman siswa yang diajar dengan menggunakan media videodan siswa yang tidak diajar dengan menggunakan media video kelas XI IPA SMA Negari 11 Makassar dinyatakan diterima dan $\mathrm{H}_{0}$ yang menyatakan bahwa tidak ada perbedaan yang signifikan antara kerampilan menulis karangan sederhana bahasa Jerman siswa yang diajar dengan menggunakan media videodan siswa yang tidak diajar dengan menggunakan media video kelas XI IPA SMA Negeri 11Makassar ditolak. Oleh karena itu, dapat disimpulkan bahwa penelitian tentang keefektifan Penggunaan Media Video efektif dalam Keterampilan Menulis Karangan Sederhana Bahasa Jerman kelas XI IPA SMA Negeri 11 Makassar.

\section{KESIMPULAN}

Berdasarkan permasalahan, tujuan penelitian, hasil analisis dan pembahasan yang telah dipaparkan, maka dapat disimpulkan bahwa penggunaan Media Video efektif dalam keterampilan menulis karanagn sederhana bahasa Jerman kelas XI IPA SMA Negeri 11 Makassar. Hasil uji- $t$ menunjukkan bahwa nilai $t_{\text {hitung }}=3,79>$ $\mathrm{t}_{\text {tabel }}=2,002$ dengan taraf signifikan 0,05. Sehingga $\mathrm{H}_{1}$ yang menyatakan bahwa ada perbedaan yang signifikan antara keterampilan menulis karangan sederhana bahasa Jerman siswa yang diajarkan dengan 
menggunakan media videodan siswa yang tidak diajarkan dengan menggunakan media video kelas XI IPA SMA Negari 11 Makassar dinyatakan diterima. Dan $\mathrm{H}_{0}$ yang menyatakan bahwa tidak ada perbedaan yang signifikan antara kerampilan menulis karangan sederhana bahasa Jerman siswa yang diajarkan dengan menggunakan media videodan siswa yang tidak diajarkan dengan menggunakan media video kelas XI IPA SMA Negeri 11Makassar ditolak. Oleh karena itu, dapat disimpulkan bahwa penelitian tentang keefektifan Penggunaan Media Video dalam Keterampilan Menulis Karangan Sederhana bahasa Jerman kelas XI IPA SMA Negeri 11 Makassar dinyatakan berhasil.

\section{DAFTAR PUSTAKA}

Ahmad, Abdul Karim. 2007. Media Pembelajaran.Makassar: Badan Penerbit UNM Makassar.

Alek A, 2010. Bahasa Indonesia Untuk Perguruang Tinggi. Jakarta: Kencana.

Anwar. 2011. Upaya Meningkatkan Keterampilan Menulis Karangan Sederhana dengan Menggunakan Media Gambar Seri. Skripsi. Jurusan PGSD Universitas Pendidikan Indonesia.

Anitah, Sri. 2008. Media Pembelajaran. Surakarta: LPP UNS dan UNS Press.

Andi Septira Lestari. 2012. Keefektifan Penggunaan Media Audio Visual terhadap Peningkatan Keterampilan Menyimak Bahasa Jerman Siswa SMA Negeri 8 Makassar. Skripsi UNM.
Aqib,Zainal. 2013. Model-Model, Media, dan Strategi Pembelajaran Kontekstual (inovatif). Bandung:Penerbit Yrama Widya.

Arsyad Azhar. 2011. Media Pembelajaran. Jakarta: PT Raja Grafindo Persada.

Arikunto, Suharsimi. 2013. Manajemen Penelitian. Jakarta: Rineka Cipta

Asnawir dan Usman M. Basyiruddin. 2002. Media Pembelajaran. Jakarta: Ciputat Pers

Asminah. 2007. Peran Media Visual dalam Meningkatkan Motivasi Belajar Bahasa Jerman Mahasiswa Program Studi Bahasa Jerman.Skripsi. Fakultas Bahasa dan Sastra UNM.

Budinuryanta, dkk . 2008. Pengajaran Kerampilan Berbahasa. Jakarta: Universitas Terbuka.

Cecep Kustandi dan Bambang Sutjipto. 2013. Media Pembelajaran Manual dan Digital Edisi Kedua. Bogor. Ghalia Indonesia.

Mantasiah, R. 2016. Media Pembelajaran Anti Korupsi Berbasis Gender untuk Menanamkan Nilai-Nilai Kejujuran Sejak di SD. Jurnal Penelitian Pendidikan Insani, 19(2). 